\title{
Development of temporomandibular ankylosis after diagnosis of Jacob's disease: clinical and tomographic assessment
}

\author{
Desenvolvimento de anquilose temporomandibular após o diagnóstico de doença de Jacob: \\ avaliação clínica e tomográfica \\ Desarrollo de anquilosis temporomandibular después del diagnóstico de enfermedad de Jacob: \\ evaluación clínica y tomográfica \\ Rafael Linard AVELAR ${ }^{1}$ \\ Roque Soares MARTINS NETO \\ Bruno da Silva GASPAR ${ }^{3}$ \\ Raimundo Antônio de Lima PRAXEDES NETO ${ }^{4}$ \\ Paulo Goberlânio de Barros SILVA ${ }^{5}$ \\ ${ }^{1}$ Phd in Oral and Maxillofacial Surgery, PUC-RS, Adjunct Professor, Division of Oral and Maxillofacial Surgery, \\ School of Dentistry, Center University Unichristus, Fortaleza-CE \\ ${ }^{2}$ Oral and Maxillofacial Surgeon, Master Student in Dental Sciences with emphasis in Oral and Maxillofacial Surgery - Unichristus, Fortaleza-CE \\ ${ }^{3}$ Dentistry Students, Center University Unichristus \\ ${ }^{4}$ Master Student in Dental Sciences, Unichristus, Fortaleza-CE. 5. PhD in Dentistry (Stomatopathology) from the Federal University of Ceará - UFC, \\ Adjunct Professor, Center University Unichristus, Fortaleza-CE
}

\begin{abstract}
Jacob's disease is a rare condition that consists of the formation of a pseudo joint structure between the mandibular coronoid process and the zygomatic bone, resulting in limited mouth opening. The disease is difficult to diagnose and etiology is uncertain. This article describes a clinical case of a 6-year-old child with limited mouth opening, which resulted in the formation of a temporomandibular ankylosis leading to complete immobility due to delayed diagnosis and treatment of the disease. A review of this pathology and the most precise imaging exams are discussed for the early and differential diagnosis of the disease.

Descriptors: Ankylosis; Temporomandibular Joint; Temporomandibular Joint Disorders.

Resumo

A doença de Jacob é uma rara condição que consiste na formação de uma pseudo estrutura articular entre o processo coronoide da mandíbula e o osso zigomático, resultando na limitação de abertura bucal. Esta doença, de difícil diagnóstico apresenta etiologia incerta. Neste artigo é descrito um caso clínico de uma criança de 6 anos de idade, com limitação de abertura bucal, que resultou na formação de uma anquilose temporomandibular levando a uma completa imobilidade, em decorrência da demora do diagnóstico e tratamento da doença. Neste artigo é feito uma revisão sobre essa patologia e os exames de imagem mais elucidativos no diagnóstico precoce e diagnóstico diferencial desta doença.

Descritores: Anquilose; Articulação Temporomandibular; Transtornos da Articulação Temporomandibular.

\section{Resumen}

La enfermedad de Jacob es una condición rara que consiste en la formación de una estructura pseudoarticular entre el proceso coronoide de la mandíbula y el hueso cigomático, lo que resulta en una apertura de boca limitada. Esta enfermedad difícil de diagnosticar tiene una etiología incierta. Este artículo describe un caso de un niño de 6 años con una apertura de boca limitada que resultó en la formación de una anquilosis temporomandibular que condujo a la inmovilidad completa debido al retraso en el diagnóstico y el tratamiento de la enfermedad. Este artículo revisa esta patología y los exámenes de imágenes más esclarecedores en el diagnóstico temprano y el diagnóstico diferencial de esta enfermedad.
\end{abstract}

Descriptores: Anquilosis; Articulación Temporomandibular; Transtornos de la Articulación Temporomandibular.

\section{INTRODUCTION}

Coronoid process hyperplasia is a change in the shape and size of part of the mandible, which is frequently misdiagnosed. Jacob's disease is a rare condition in which a joint or pseudo joint is established between the mandibular coronoid process and the zygomatic bone $e^{1,2}$. The pathogenesis of the disease remains uncertain, but some etiologies such as temporal muscle hyperactivity, anterior injury to the coronoid process, chronic displacement of the temporomandibular joint (TMJ), endocrine stimuli, and genetic alterations may be its cause ${ }^{3}$.

Although coronoid process hyperplasia was first described by Langenbeck in 1853, joint formation between the coronoid process and the zygoma was later described by Oscar Jacob in 1899. Increased coronoid process size has been sporadically reported in the literature, but few cases of Jacob's disease have been described ${ }^{4}$. This alteration of the coronoid process is characterized by the development of abnormal bone, leading to malocclusion, limited mouth opening, which is responsible for failure in oral hygiene, and pain. Coronoid hyperplasia affects this structure and the zygomatic bone, preventing mouth opening ${ }^{5}$. There are 50 cases of Jacob's disease reported in the literature, but only 39 diagnosed cases presented histological changes suggestive of the formation of a pseudo joint. Men are predominantly more affected (63\%) and it is mainly diagnosed at the age of 30 years. The most accepted treatment is resection of the coronoid process $^{6}$.

In this case report we will discuss the case of a child patient who presented bilateral coronoid hyperplasia with the onset of a pseudo joint formation consistent with Jacob's syndrome/disease.

\section{CLINICAL CASE}

A 6-year-old child was referred to the Department of Surgery with a history of limited mouth opening that began 2 years earlier and had been first diagnosed by a dentist as a TMJ disorder. Initially the patient was treated with AINES and analgesics due to pain during mandibular movement. A CT scan revealed coronoid process hyperplasia without alteration of the left and right temporomandibular joints (Figure 1). 
After progressive clinical aggravation and no effective treatment for two years, left and right coronoid process hyperplasia was observed at her first consultation. At this stage of treatment, the patient presented no mandibular mobility, Class II facial profile, feeding mainly through the space between the upper and lower central incisors, since the patient had lost deciduous teeth

The 3D computed tomography revealed bilateral temporomandibular ankylosis due to immobility caused by coronoid process hyperplasia and the patient's mother reported that mouth opening, which used to be 10 and $20 \mathrm{~mm}$, became practically non-existent over the last two years.

The CT revealed right coronoid process with a discrete facet extending to the superior and lateral side of the mandible. The articular spaces between the condyle and the glenoid cavity were absent, which confirmed the diagnosis of TMJ ankylosis (Figure 2). The patient was admitted to hospital and pre-auricular access and Risdon incision were performed bilaterally after nasoendotracheal intubation. Removal of bilateral temporomandibular ankylosis and resection of the coronoid process hyperplasia were performed.

After these procedures, the costochondral graft was removed to reconstruct the temporomandibular joints, aiming to promote mandibular growth in the postoperative period (Figure 3). The patient is in postoperative follow-up, with no signs of relapse and $28 \mathrm{~mm}$ of mouth opening.

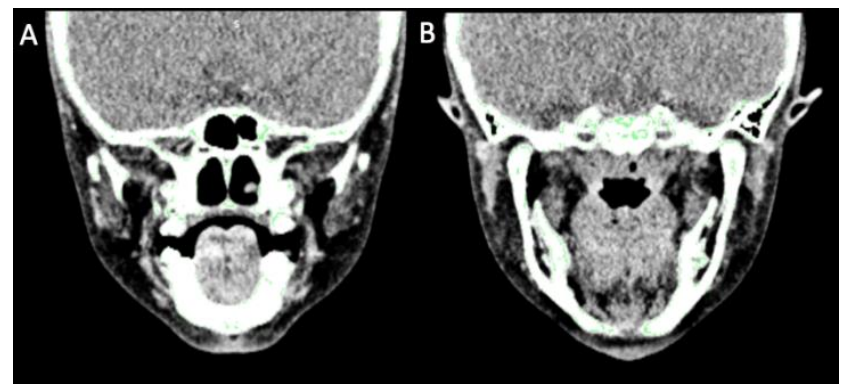

Figure 1: Computed tomography at axial section. A - Bilateral Coronoid Hyperplasia. B - Absence of morphological changes in the mandibular condyles.

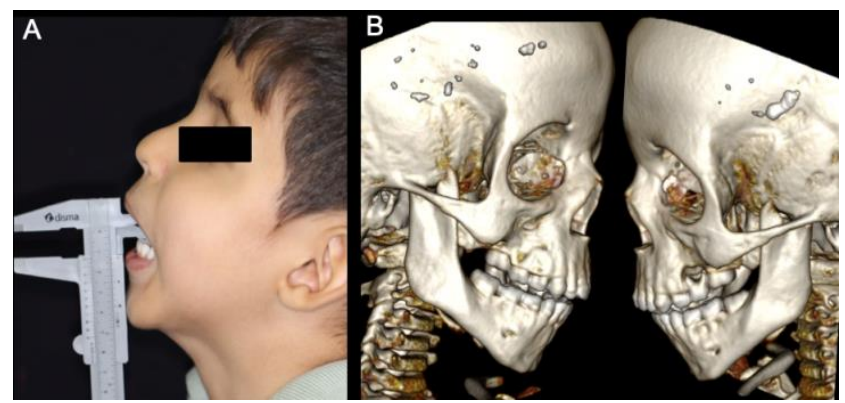

Figure 2: A - Clinical view of profile showing limited mouth opening. B- Bilateral coronoid hyperplasia and absence of joint space, compatible with temporomandibular joint ankylosis.

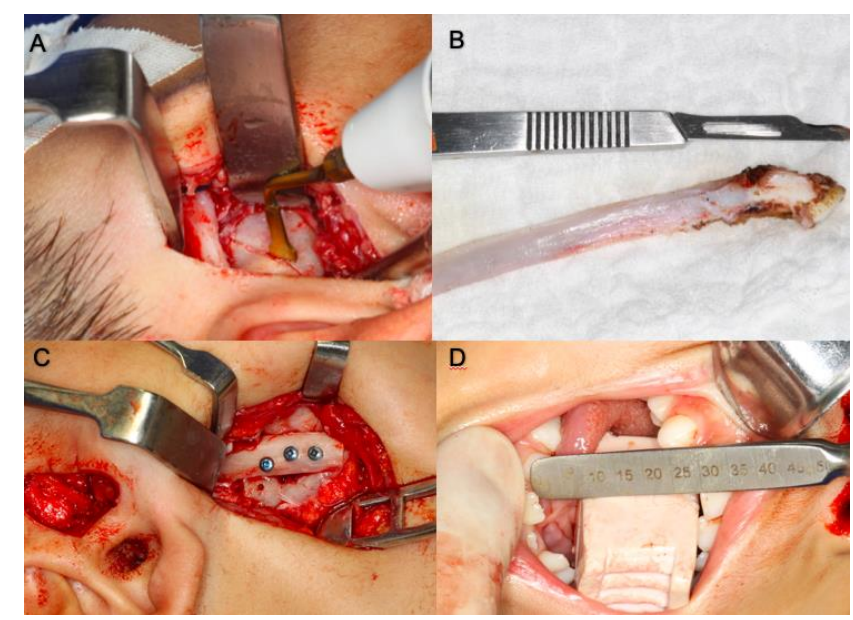

Figura 3: A - Pre-auricular access, GAP arthroplasty for ankylotic block resection by piezosurgery. B - Costochondral graft removal for joint reconstruction. C - Adaptation and fixation of the costochondral graft. D - Oral opening obtained after resection of the ankylotic block and joint reconstruction.

\section{DISCUSSION}

Jacob's disease is a disease with discrete clinical symptoms, leading to a progressive reduction of mouth opening if initial diagnosis and definitive treatment is delayed ${ }^{6}$. Lateral deviation in mouth opening when only one side is affected or alteration in the malar region can be a strong indication of the disease $^{7}$. In the present case, the patient presented coronoid process hyperplasia, belatedly diagnosed, which led to the development of temporomandibular ankylosis.

Posteroanterior Water and panoramic radiographs may be the first exams to be performed in a patient with suspicion of Jacob's disease ${ }^{8}$, although in many cases the professional may be led to believe that it is related to dysfunction of the temporomandibular joint at first examination. A history of progressive pain in the TMJ months before the initial consultation may be what leads to misdiagnosis, leading the practitioner to request an MRI of the TMJ. In some cases, a slight asymmetry of the zygomatic area has been described in some reports ${ }^{4,9}$.

Computed tomography is the most frequently used exam not only for diagnosis but also for planning the surgical procedure ${ }^{4,10}$. The 3D-CT is the most valuable tool for planning the surgery ${ }^{9,10,11}$.

Computed tomography imaging may reveal osseous details of the coronoid process and a possible relationship between the coronoid process and the zygomatic bone ${ }^{4}$, which was the case on one of the sides of our patient, and a discrete amount of tissue was observed in the inner surface of the zygomatic bone during the operative procedure.

When Shackelford and Brown ${ }^{12}$ reported 2 cases of coronoid process hyperplasia for the first time, there was much confusion as to the basic nature of this condition. The differences in the proportion of cartilaginous and bony elements in the specimen justified several histological diagnoses, among which 
include: osteochondroma, osteoma, exostosis and hyperplasia $^{9}$, our case being diagnosed as hyperplasia.

Osteochondroma is a benign neoplasia that develops most frequently between the ages of 10 and 30 years, being responsible for several cases reported in the literature ${ }^{10}$. As in most patients with Jacob's disease, it probably extends from the periosteum, forming areas of metaplastic cartilage ${ }^{13}$. In the present case, immature bone tissue was found on both sides, with limited amount of fibrous tissue, not being compatible with the diagnosis of osteochondroma.

Surgical procedures to treat Jacob's disease may be intraoral, extraoral, or a combination of both. Intraoral access eliminates the need for external scarring and decreases the risk of facial nerve damage. Although extraoral access is less esthetic, it provides greater surgical visualization ${ }^{4}$. The choice must be based on the experience of the surgeon and the size/extent of the coronoid process. In the present case, two extraoral accesses were performed due to the large size of the coronoid process hyperplasia and need to remove the mandibular condyles and place the costochondral graft.

\section{CONCLUSION}

The 3D-CT is the gold standard for preoperative diagnosis, although the final diagnosis is based on histological analysis and presence of a jointlike structure between the coronoid process and the zygomatic bone, being important from the diagnostic phase to surgical planning.

\section{REFERENCES}

1. Wang WH, Xu B, Zhang BJ, Lou HQ. Temporomandibular joint ankylosis contributing to coronoid process hyperplasia. Int J Oral Maxillofac Surg. 2016;45(10):1229-33.

2. Zhong SC, Xu ZJ, Zhang ZG, Zheng YH, Li TX, Su $\mathrm{K}$. Bilateral coronoid hyperplasia (Jacob disease on right and elongation on left): report of a case and literature review. Oral Surg Oral Med Oral Pathol Oral Radiol Endod. 2009 Mar;107(3):e64-7.

3. Coll-Anglada M, Acero-Sanz J, Vila-Masana I, Navarro-Cuéllar C, Ochandiano-Caycoia S, López de-Atalaya J, Navarro-Vila C. Jacob's disease secondary to coronoid process osteochondroma. A case report. Med Oral Patol Oral Cir Bucal. 2011;16(6):e708-10.

4. Yesildag A, Yariktas M, Doner F, Aydin G, Munduz M, Topal U. Osteochondroma of the coronoid process and joint formation with zygomatic arch (jacob disease): report of a case. Eur $\mathrm{J}$ Dent. 2010;4(1):91-4.

5. Çorumlu U, Kopuz C, Demir MT, Pirzirenli ME. Bilateral elongated mandibular coronoid process in an Anatolian skull. Anat Cell Biol. 2016; 49(3):217-20.

6. Choi JG, Kim SY, Perez-Atayde AR, Padwa BL.
Bilateral coronoid process hyperplasia with pseudocartilaginous joint formation: Jacob disease. J Oral Maxillofac Surg. 2013;71:316-21.

7. Losa-Muñoz PM, Burgueño-García M, GonzálezMartín-Moro J, Sánchez-Burgos R. Osteochondroma of coronoid process: a rare etiology of jacob disease. Craniomaxillofac Trauma Reconstr. 2014;7(4):306-9.

8. Escuder i de la Torre O, Vert Klok E, Marí i Roig A, Mommaerts MY, Pericot i Ayats J. Jacob's disease: report of two cases and review of the literature. J Craniomaxillofac Surg. 2001;29(6):372-76.

9. Hernández-Alfaro F, Escuder O, Marco V. Joint formation between an osteochondroma of the coronoid process and the zygomatic arch (Jacob disease): report of case and review of literature. J Oral Maxillofac Surg. 2000;58(2):227-32.

10. Sreeramaneni SK, Chakravarthi PS, Krishna Prasad L, Raja Satish P, Beeram RK. Jacob's disease: report of a rare case and literature review. Int J Oral Maxillofac Surg. 2011;40(7):753-57.

11. D'Ambrosio N, Kellman RM, Karimi S. Osteochondroma of the coronoid process (Jacob's disease): an unusual cause of restricted jaw motion. Am J Otolaryngol. 2011 JanFeb;32(1):52-4.

12. Shackelford RT, Brown WH. Restricted jaw motion due to osteochondroma of the coronoid process. J Bone Joint Surg Am. 1949; 31A(1):107-14.

\section{CONFLICTS OF INTERESTS}

The authors declare no conflicts of interests.

\section{CORRESPONDING AUTHOR}

Roque Soares Martins Neto

e-mail: roquemartinsn@outlook.com

Received 17/08/2019

Accepted 20/04/2020 